\title{
PLATONIC METHODOLOGICAL ALTERATIONS: ELENCHUS, DIALECTICS, AND DIAERESIS
}

\author{
Abdolrasool Hasanifar \\ University of Sistan and Baluchestan, Iran \\ Seyedmohsen Alavipour \\ Institute for Humanities and Cultural Studies, Iran
}

\begin{abstract}
Whether all the Platonic dialogues are parts of an inconsistent or consistent body is a controversial subject of philosophy. Indeed, though in form all the texts are written dialogically, in content, one might recognize methodological alterations in Platonic thought from the 1st book of The Republic to later dialogues such as The Statesman and The Laws. However, how much this methodological alteration might affect the content of Plato's political philosophy, the relation between the rupture in the method of contemplation on the one hand and the structure of the Platonic ideal Polis is still a subject not seriously explored yet.

Exploring the characteristics of the three different methods used in Plato's different dialogues, the present study attempts to show that in the light of the methodological alteration, one might realize how Platonic understanding of the good society has changed from The Republic to The Statesman and The Laws.
\end{abstract}

\section{INTRODUCTION}

While at the end of the first book in Republic, it seems that the epistemological conversation over justice has ended, at the beginning of the second book, the dialogue continues but with great differences, which might lead to the conclusion that textually, the two books are different not only in the mode but also in the content of the debate. Indeed, while in the first book, Thrasymachus is the debater who is apparently introducing his own definition of justice, and against whom Socrates negatively challenges (nevertheless emphasizes that he has no idea of the subject); in the second book, Thrasymachus's position as the interlocutor is replaced by Glaucon and Adeimantus (Plato's brothers), whose role, due to their characteristics and long-term loyalty to Socrates, is just to endorse Socrates' positive argument about the what-ness of justice and how to apply it in the polis. In other words, converting a civil dialogue into a family discussion (See Lycas 1987, 25) and taking a like-minded debate over a challenging one yields to a dialogue in which, instead of explorative searching for 
truth, the parties' questions are intended to lead to a justified argument on justice merely. In positively speaking in the second book, the ignorant Socrates (who knows that he knows nothing) suddenly turns into an omniscient wise man that has definitive insights about the Idea, Soul, Virtue, the Philosopher-king, etc.; the one who has the answer for all questions! He is not using the Elenchutic method in the debate anymore and instead prefers the dialectical one in which he is eligible to judge over everything and decree the truth.

The question is whether Plato's Socratic method (Elenchus), which is apparent in the earlier dialogues, namely Apology, Lysis, Charmides, Euthyphro, Hippias, etc., has altered in his middle period texts, namely Cratylus, Euthydemus, Meno, Parmenides, Phaedo, Phaedrus, Republic, Symposium, etc., into a so-called dialectical one? Whether this was solely a change in method, or it also implies an evolution in Plato's intellectual attitude? How and why this alteration in method happened? And while it is not the only methodological change throughout Plato's intellectual life (as we shall see, in the Statesman, his intellectual methodology reconverts into Diaeresis), one might ask due to what exigencies, Plato found himself needy of a methodological conversion from Elenchus into Dialectics and then Diaeresis? Is this a sign of a fundamental rupture in Plato's understanding of a good society? If so, how might this be elaborated?

Although some scholars, such as Eduard Zeller (Morrow 1993, 309), based on denying the authenticity of some dialogues, namely The Laws, consider the subject even out of the question, in the Unitarian approach (Smith 1999, 299-301), there is neither formal nor intellectual alternation seen in Platonic philosophy throughout the first to the last dialogues. Here, all the Platonic dialogues are solely parts of a coherent corpus, all together forming his consistent philosophy. As a prominent advocator of this view, Schleiermacher argues that Plato has consciously arranged his dialogues on a general classification which leads him to a definite goal. Indeed, due to Schleiermacher, not only there an inter-relational consistency is evident in the continuum of Platonic dialogues, but also aware of this feature, and based on it, he attempted to introduce his philosophy is not a dogmatic schema but in a dynamic dialectical approach (Schleiermacher 1973, 27-28).

Nevertheless, some scholars emphasize the evolutionary feature of Platonic dynamic intellectual endeavors. Due to this recounting, though seemingly there might be paradoxical features in parts of The Republic and some other dialogues, it is indebted to Plato's lived-experiences in his journey to Syracuse, which helped him to reconsider the applicability of the idea of Philosopher-King in reality. In other words, while in his later contemplation on the obstacles a virtuous Philosopher-King might encounter in the real non-virtuous city-state, he confessed that the idea is unrealizable and so, one should search for less-virtuous models of governing, among which the rule of law is the best ruling-style; the confession for which The Statesman and The Laws are documents. Among the scholars who argue for such an account, Leo Strauss (1975) believes that The Laws is only the encoded, articulated schema of the virtuous city-state Plato figured out in The Republic. While Ross $(1953,118)$ supposes that it is the transformation of the concept of Idea that causes the alteration in the meaning of dialectic from The Republic to the Sophist and The Statesman, Strauss $(1987,33)$ finds this evolution part of an ontological change in methodology. For, while in philosophical approach to the what- 
ness of the good, one is able to behold it in its ideal manifestation, in a political one, only knowledge of ignorance is possible, which solely leads to the deprivation and not to the norm description. In other words, while both dialogues are dialectical, the first is an idealbased one, while the other is experiment-based (Strauss 1987, 70). So, as Barker (1964, 135) puts it, The Statesman is a bridge that connects the idealistic The Republic to the experimental Laws through transforming the author from the living intelligence to the law. On such debate, one might find Lane's $(1998,15)$ interpretation of Plato's methodological alteration as only a technical trick comprehensible. In Friedlaender's account $(1969,290)$, the same understanding of the subject is obvious; however, he stresses the law-making role of the philosopher and argues that based on what he has learned throughout the educative process, the philosopher-king is finally capable of applying his knowledge in a social system for which the laws are the foundations.

On the other hand, recognizing the alteration of Platonic language in his later dialogues, some scholars (Lane 1998; Pangle 1980) believe that the differences are just the representations of different aspects of the same question in which the foundations have never changed. It is solely Platonic alteration of focus from theoretical to the practical side of the subject that encouraged him to contemplate on the realization of philosopher-king's authority in a multi-layer political society for which The Statesman and The Laws are the elaborations, where one might find the practical pieces of advice of a philosopher to an executive politician in state-building. Kahn (1995, 53-4) even relates this to Plato's psycho-physical changes due to his aging and the failure of his attempt to realize the philosopher-king in Syracuse. It seems that Plato is making his will for the future Athenians in an attempt to formulate a law-based general institutionalizing the polis.

Klosko $(2006,199)$, and Saunders $(1998,326)$ too, argue for Plato's intellectual evolution from the idealistic Republic to the more realistic Statesman and Laws and find either Platonic Sicilian endeavors as the origin of the alteration or merely Platonic tending to make changes in his Republican theory of the society. An account for which Morrow (1993, 573-577) is also an advocator.

However, as is seen, no scholar has yet paid attention to the contribution of methodological revision in Platonic intellectual endeavor from The Republic to The Laws. Indeed, differences might be simply comprehended as neither the different facets of the same intellectual corpus nor coherent entities of a developing philosophy in which the alteration is solely from theoretical to practical aspects, but as the evidences of a methodological rupture which led Plato to fundamentally change his idea of a good society. By considering the methodological alternations as the signs of evolution in the Platonic political approach, the present study attempts to comparatively explore Elenchus, Dialectic, and Diaeresis and show how these methodological foundations might affect Plato's dialogues, and consequently, shape his intellectual approach towards politics.

\section{SOCRATIC ELENCHUS}

Due to the distinctive characteristics of the dialogue, The Republic's first book (and some above-mentioned earlier dialogues) is thought to represent the historical 
Socrates whose methodological approach to dialogue, the Elenchus, dominates the debate. Driving from elenchein, which means to scrutiny, and correct somebody's mistaken belief through argumentation and inquisition (Peters 1967, 51), Elenchus is named for the way Socrates challenges the people who believe to be knowledgeable about something in order to reveal the superficiality of their knowledge. He makes the debater face the paradoxes underneath his beliefs in order to dissolve his knowledgepride and so to prepare him for the correct episteme (Robinson 1996, 15). In doing so, Socrates first would ask the debater to explain his view about an ethical virtue. Then, based on this view, Socrates would ask some questions about its foundations and introduce the challenges one should consider in his formulation of the subject. In such a way, the debater is driven to accept that there is a correct view that contradicts his own ideas, and so, it is clear that his view needs to be modified (Vlastos 1991, 46). Naming the method "maieutic" (midwifery), Socrates attempted to make the debater aware of his ignorance and so conduct him to seek the correct episteme and then base his individual and civic life upon it. In other words, as is clear in the first book of The Republic, Elenchus is a way to free the prisoners of the illusions and instruments of their nascent intellectual freedom (See Smith 1999, 198).

The other aspect of Elenchus is the famous Socratic irony in which he not only ridiculed the debater but also, due to his merely asking questions and never offering answers, made the party angry. One might find evidence for this throughout the earlier dialogues, i.e., in Thrasymachus' nervousness in the first book of The Republic, in which he condemned Socrates for his always ironically questioning and never stating his own view on the subject matter (See Plato 2004, The Republic, 336b). However, as Jaspers (1966) puts it, Socrates never aimed just to ridicule others but to show their ignorance and make the unutterable truth obvious in such a way that even the debater would endorse it.

\section{PLATONIC DIALECTIC}

Driving from dia, which means either the mutual encounter or the way, and lactic which means "to converse," the term "dialectic" could be defined as the manifestation of truth through conversation and so, leveled as a high transcendental philosophical method (Peters 1967, 36). The term dates back to the pre-platonic Athenian philosophical discourse, and Aristotle assigns it to Zeno of Elea (See: Urmson 2001, 40). However, while Platonic dialectics has its roots in Socratic Elenchus (Fine 1998, 257), Plato's confounding role is to recruit it as a dialogical question-and-answer towards the comprehension of truth, based purely on the intellectual drive, where feelings and impressions have no way in. In other words, for Plato, Dialectics is in no way a mystical intuition, but a purely intellectual activity:

Dialectic is the only investigation that, doing away with hypotheses, journeys to the first principle itself in order to be made secure. And when the eye of the soul is really buried in a sort of barbaric bog, dialectic gently pulls it out and leads it upward, using the crafts we described to help it 
and cooperate with it in turning the soul around (Plato 2004, The Republic, 533 c-d).

However, to understand Platonic dialectic, one first should pay attention to the method of the hypothesis he introduces in Meno and Phaedo. It is in Meno which he, for the first time, recruits this method to elaborate "whether virtue is given by instruction or in any other way" (Plato 2004, The Republic, 86e). Answering such a question, Plato reminds of the geometrical hypothesis which a geometrician might recruit to flesh out differences between geometrical shapes. Nevertheless, such method of hypothesis might even help the philosopher in his purifying endeavor to get the truth:

I started in this manner: taking as my hypothesis in each case the theory that seemed to me the most compelling, I would consider as true, about cause and everything else, whatever agreed with this, and as untrue whatever did not so agree. But I want to put my meaning more clearly for I do not think that you understand me now... (Plato 1997, Phaedo, 100a)

Repeating this purification of the truth from the untrue, Plato affirms, one should examine anyone who attacks his hypothesis through examine "whether the consequences that follow from it agree with one another or contradict one another" (Plato 1997, Phaedo, 101d). This hypothetical method would obviously lead the explorer to sieve the true from the untrue. But this only would happen through the

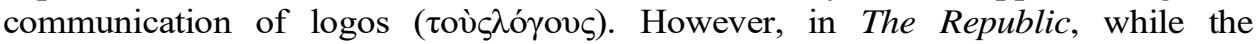
exploration of the good as the authentic knowledge is the point, one might only investigate for the ideal hypothesis, which is the Idea. So, the method should also purify to a refined intellectual hypothesis, which is the dialectic.

But first of all, it should be clear that what necessities led Plato to alter the debate's methodology from Elenchus to dialectic? The answer could be found in the Platonic allegory of the cave. Here, while all people are besieged in their impressions and enchanted by the wall pictures that misguide them from reality, only a few, namely the philosophers, could understand that the wall pictures are just representations of what is real and not reality itself. Their exodus from the cave would guide them to the sun itself, as the sign of the idea of good, and they discover it as the origin of all the comprehensions and feelings, which is also the only way to attain knowledge about them. However, the philosopher, who has comprehended the idea and is the only qualified person to act in both realms of the intellect and impressions, needs to get dialectical education for which nobody else is eligible:

Sight tries at last to look at the animals themselves, the stars themselves, and, in the end, at the sun itself. In the same way, whenever someone tries, by means of dialectical discussion and without the aid of any sense-perceptions, to arrive through reason at the being of each thing itself, and does not give up until he grasps what good itself is with understanding 
itself, he reaches the end of the intelligible realm, just as the other reached the end of the visible one (Plato 2004, The Republic, 532a).

Unlike the Elenchusian approach in which all people, no matter how much they are educated and regardless of their natural element, are capable of participating in the dialogue towards the manifestation of truth, only people of a unique nature are eligible for the dialectical endeavor. So, surveillance should pay great attention to not let the unworthy people to get access to the instruction, for otherwise, it might lead to evil and rebellion (Plato 2004, The Republic, 573e). Misuse of knowledge also might lead to the misunderstanding of the value of great virtues such as justice, the good etc. (Plato 2004, The Republic, 539d), for here one should put all the un-intellectual limitations and assumptions aside and occupy his mind solely by what is real and comprehendible through intellectual perception (Plato 2004, The Republic, 477d). Dialectical knowledge is the pure knowledge of the ideas and typically the idea of the good (Plato 2004, The Republic, 511b). This knowledge not only is exculpated from the impressions, but is also total and all-included (Struass 1987, 69); for which all the other steps of instruction (which are based on assumptions) are preparatory. In Plato's expression, they just can help to open the bonds and help the quester to begin his voyage to see the sun (Plato 2004, The Republic, 532d).

In order to distinguish different steps of knowledge, Plato appeals to the allegory of line in which there are four different levels of episteme, the lower two of which belong to the perception of the visible world, while the upper two are exclusive to the intelligible world. In the two lower steps, one is capable of first acquiring an illusionary

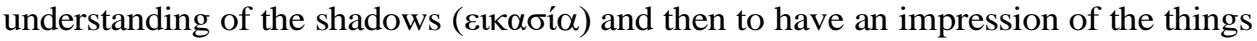
themselves $(\pi \imath \sigma \tau \imath \varsigma)$. However, in the two upper steps, one is equipped with knowledge which enables him to first introduce an intellectual hypothesis on the intangible world $(\delta 1 \alpha v o t \alpha)$ and finally, to comprehend the reality of the ideas (vónбís) (See: Plato 2004, The Republic, 509e-411e).Characteristically, in the first steps, one learns mathematics, then geometrical knowledge, music, and astronomy, and only after passing such instructions would he be eligible for the highest knowledge, which is the dialectical (Plato 2004, The Republic, 505a) and there, ideas leads him to the perception of the idea of good:

Also understand, then, that by the other subsection of the intelligible I mean what reason itself grasps by the power of dialectical discussion, treating its hypotheses, not as first principles, but as genuine hypotheses (that is, stepping stones and links in a chain), in order to arrive at what is unhypothetical and the first principle of everything. Having grasped this principle, it reverses itself and, keeping hold of what follows from it, comes down to a conclusion, making no use of anything visible at all, but only of forms themselves, moving on through forms to forms, and ending in forms. (Plato 2004, The Republic, 511 b-c)

To learn such knowledge, the learner must first get a 5-year theoretical instruction and then apply it practically for fifteen years in his civic life in the polis 
(Plato 2004, The Republic, 511b-d). His intellect here is unrestricted from all the mediator assumptions and is capable of unlimitedly grasping the totality. He is now the lover of seeing the truth (Plato 2004, The Republic, 475e).

\section{DIAERESIS}

The alteration from Elenchus to Dialectics is not the only methodological conversion in Platonic dialogues. Late Plato's Sophist and Politicus are methodologically based on a different approach called Diaeresis (dividing). Indeed, the alteration is so obvious in the Politicus that some scholars (See: Bern, 1919; Lane, 1998; Schofield, 2006) believe that the central point in the dialogue is its methodological approach which has made it primarily a text of logic. It is clear that Plato himself is aware of the importance of the issue of method in the dialogues and emphasizes the necessity of methodological discussion at the dawn of exploring different aspects of Politicus (Plato 1997, Statesman, 286e).

However, some scholars have gone further. For instance, Schofield $(2006,165)$ states that the method has directly shaped both the content and the ones who play as the debaters in the dialogues. As Lane (1998, 2-3) argues, here, not only the definition of politics but also the method is attributed to the what-ness of the political skill and how to differentiate it from other civil skills. In other words, articulating this skill and even defining who the politicus is exclusively subjected to the methodological dividing (Diaeresis). According to Plato (Plato 1997, Statesman, 286e) Diaeresis is the method of division into categories. Here, each concept is considered as articulated such that one could continuously divide it into two parts to get closer to the exact meaning of the concept. The final step in the process is where the definition of the subject is totally differentiated from other similar concepts. In other words, the definition of any concept is step by step demarcated from the general meaning in order to get totally purified (See: Peters 1967, 34; Klosko 2006, 201). For instance, defining the statesman follows the same process in which, at first, knowledge is divided into two different parts, namely the practical (art of work) and the theoretical (art of enlightenment), and the statesman should be equipped with the latter. Then the theoretical knowledge is itself divided into judgment and leadership, where again, the latter is the division which the statesman shall be equipped with and so on. The eleven-step division leads to the pure knowledge that the statesman's situation demands (Plato 1997, Statesman, 259c, 258b-267b):

Knowledge
Practical/ Theoretical
Judgment/Leadership
Hired Leadership/ Independent Leadership
Leadership to create inanimate objects/Leadership to create and train animals
Leadership for individual animals/ Leadership for Herbivorous animals
Aquatic animals/ Terrestrial animals
Flying animals/ Landing animals
Horned animals/ Non-Horned animals
Heterosexual/ Homosexual




\section{Horizontal/ Vertical (human)}

Non-political man/ Political man.

The Diaeresisian approach is divided into two different types; first, the relative measurement, applicable to length, velocity, and depth, and then the measurement per se, suitable for finding the mean measure between two limits (Plato 1997, Statesman, 284e). The latter is so important that Plato argues there is no distinct knowledge without it (Plato 1997, Statesman, 284d). To confidently find the mean measurement, one must surely distinguish between the two types and base the division on the latter:

I think that we had better not cut off a single small portion which is not a species, from many larger portions; the part should be a species. To separate off at once the subject of investigation is a most excellent plan if only the separation be rightly made, and you were under the impression that you were right because you saw that you would come to man, and this led you to hasten the steps. But you should not chip off too small a piece, my friend; the safer way is to cut through the middle, which is also the more likely way of finding classes. Attention to this principle makes all the difference in a process of enquiry.

Whereas you would make a much better and more equal and logical classification of numbers, if you divided them into odd and even; or of the human species, if you divided them into male and female; and only separated off Lydians or Phrygians, or any other tribe, and arrayed them against the rest of the world, when you could no longer make a division into parts which were also classes. (Plato 1997, Statesman, 262 a, b \& e).

For Plato, the Politicus is the one who can correctly use the measurement in the polis and organize it based on the mean measurement in all aspects (Klosko 2006, 201-202).

\section{IMPLICATIONS OF PLATONIC TRANSITIONS}

Due to Socrates' emphasis on his ignorance and his attempt to reveal to others that, despite their pseudo-enlightened-ness, they are too unlearned on the subject, Socratic Elenchus is directed towards no positive thesis. Indeed, all early Platonic dialogues, namely Apology, Lysis, Charmides, Euthyphro, and the first book of The Republic, are open-ended in which the only positive result is that the debater is guided to know that he does not know either. At the end of Lysis or Laches, there is no definition respectively for friendship or courage, though the interlocutors have had a long discussion over different might-definitions of the subject. However, it does not mean that there is nothing to learn from Socrates in his Elenchus. Indeed, the most important knowledge for Socrates is that he knows that he knows nothing and he teaches others the same, and the final evaluation of the debaters shows that they are satisfied by their new enlightened-ness. 
It is true that if the dialogue would lead to a positive knowledge, it would totally violate Socrates' pride of ignorance. Socrates was concerned with his heavenly mission to show the paradoxes of the different answers to the same question of definition (See Robinson 1996, 9), and so, to just clarify the difference between doxa and episteme. However, despite the clarification, there is no explanation over the whatness of episteme. In other words, Socrates enlightens others on their mistaken doxa without telling them anything about the why-ness of their ignorance over their ignorance (Robinson 1996, 18). Even for Socrates, there is no clear way toward correctness. He relies on the daemonic inspirations, which only conduct him away from the wrong beliefs without guiding him towards the right ones. Socratic daemons are also negatively cooperating on the way towards the enlightened-ness (See: Plato 1997, Apology, 31d-40a). Thus, on this level, Socrates is by no means a philosopher who is concerned with introducing a universal apparatus in which all aspects of human life are defined and systematically ranged. He is only an explorer of moral virtues who has some ethical inspirations to offer (See Ross 1996, 30; Chroust 1996, 42).

Indeed, despite the ironic aspect of Elenchutic conversation, which help the debaters to compromise over their ignorance of the reality of the subject, what first of all matters is the provision that both sides stay on a similar level of knowledge and are able to barely and honestly state their own view in order to get into a parallel knowledge of the matter. Hence, in Elenchus, there is no way for a knowledgeable, wise man to positively teach others what the reality is and how he might pave the way towards the truth. In other words, when a party stays on the side of the positive truth, no Elenchutic conversation could happen (See: Graham 1996, 190).

It is clear that such an intellectual approach would by no means lead to an organized political system, and for Plato, who seems to be concerned with the construction of the good political order, this might not be enough. He needed a philosophical positive approach that could lead to a transition from doxa towards an intellectual episteme containing the reality of the subjects and guide the population to the idea of the good. Due to its positive, explorative, and explanative aspects, Dialectics was the substitution Plato considered for Elenchus (Robinson 1996, 19). Thus, based on the property of discovering and disclosing the correct, Plato considered Dialectics the only way to organize the polis alongside the light of truth.

However, it is not the only cause why Plato substitutes Dialectics for Elenchus. Furthermore, while Dialectics contains an intellectual discourse towards the truth per $s e$, Plato applies it in his conflict with the Sophist, whose justification is empirically based on the human experiment and tendency. Plato, on the contrary, believes that due to its temporality, what is obtained via the sensual understanding is merely doxa and is not applicable to the general, invariant realities of which the only reliable knowledge is the non-sensual one with no reference to experiment. In other words, what is perceived in the real intellectual understanding is the transcendent Ideas, which are prominently over the variable objects, and it is only through dialectical reasoning that the philosopher might be eligible to comprehend them.

Hence, in contrast to the incapacity of Sophists' experimental relativism for a definitive organization of the polis, Dialectics is the innermost reality of philosophy through which the philosopher is equipped with a pure comprehension of the good, as 
the $a$ priori and the most fundamental rationale for the existence of truth and virtue (Annas 1981, 279).Thus, as is seen in the second book of The Republic onwards, defining the good political order becomes the philosopher's most important mission, which he fulfills through the dialectical dialogue as an ideal educative program (See: Peters1967, 36).Indeed, this is the reason why the philosopher is the only one capable of ruling the polis; for, his dialectical knowledge conducts him towards the ideal order of the state and thus, lets him legitimately find or lead the political institutions exclusively. So, due to their similar reference to the non-sensual knowledge, the philosopher and the dialectician are the same, and there is no sign to differ them; methodologically, it is called Dialectics, and with regard to the content, it is named philosophy (Jaspers 1966, 10-20). Plato puts it in interrogative expression:

So don't you, too, call someone a dialectician when he is able to grasp an account of the being of each thing? And when he cannot do so, won't you, too, say that to the extent that he cannot give an account of something either to himself or to another, to that extent he does not understand it? (Plato 2004, The Republic, 534b).

In Platonic dialectical organization of polis, the philosopher/dialectician is the one who exclusively knows the ideas, and mainly the idea of the good, and so, obviously, the good political order is only under the rule of the philosopher. Based on such dialectical epistemology, the rest of The Republic prescribes the procedure to find and educate the philosopher who is supposed to lead the polis towards goodness.

However, exploring the later Platonic dialogues, one might infer that unlike the dialectical reasoning's emphasis on non-sensuality, the divisional methodology proposed in the Statesman (as seen above) is basically founded on dichotomies whose criteria is the objective sensual differences. In this way, to know the nature of the statesman and the way to distinguish him from the others, one has to first attempt to understand the difference between the rule over the animate and inanimate creatures; the individual and the social ones; the aquatics and the Terrestrials. As is obvious, all the criteria are sensual and objective.

The question is whether it is a clue for the second alteration in methodology in Platonic thought?

Indeed, there is no consensus among scholars over such an alteration. In other words, while Strauss and Cropsey $(1987,70)$ argue that even in the Statesman, Plato is methodologically loyal to dialectic; though not the non-sensual, but the experimental one; Guthrie (1978, 166-168) believes that Platonic methodology in Statesman, namely the Diaeresis, is the practical classification through which Aristotle significantly inspired (scientific Biology. On the other hand, considering it as a logical technic, Lane $(1998,15)$ calls the differentiation Plato suggests here the "actual division," which is more or less a rational method and a technique.

However, Gomperz $(1912,3)$ calls the new Platonic Methodological approach "the natural history" in which human activities and matters are classified in imitation to the natural ordering of the animals and plants. According to him, this approach was appreciated in Platonic Academy; however, it was actually Aristotle who developed it. 
On the other hand, some scholars explain such an alteration in method in the light of the deep changes that happened in Plato's understanding of the ideas (Forms). Ross $(1953,118)$ argues that due to Plato's discourse in Parmenides and Sophist, it is plausible to suggest that his conception of the ideas has changed in his later thought and so, one might claim that based on such variation, in comparison to the Republic, the very meaning of the concept of Dialectics has changed in Phaedrus, Sophist, and Statesman.

Indeed, on the one hand, while in the dialectic it is only the philosopher who is capable of knowing the ideas, especially the idea of the good, in Diaeresis there is no exclusivity and anyone who is sufficiently competent to recognize the point of articulation is qualified to know the truth. In other words, while, according to Gadamer (1986, 121-122), Dialectics is not only a method but a style of a living philosopher, Diaeresis is just a method citizen from different classes are able to learn. On the other hand, dialectical comprehension is based on a philosophical, intellectual exploration of the general concepts, but Diaeresis is concerned with the worldly, sensual subjects to understand which the one is needless of sophisticated philosophical reflections (See Gomperz 1912, 3-10).

Due to such an epistemological differentiation, unlike the dialectics, in Diaeresis, leadership in the polis is not dependent on the leader's intellectual qualifications to understand the general ideas but is based on exact, transparent laws articulated due to the knowledge of divisions (Plato 1997, Statesman, 297a). Hence, since contrasting to the general everlasting paradigm of politics and government in The Republic, where the dialectical distinction between the good and the evil is merely conditioned to the ethical criterion, in the Statesman measurement and technical differentiation is the decisive factor, politics is not anymore a knowledge, but a skill of statesmanship and estate management (Lane 1998, 124-5). Here, the statesman is the weaver for whom merging the fiber of the polis due to the correct measurement and division standards is the political art he needs to find and build the best order of the society (Plato 1997, Statesman, 305e).

As a result, while in Dialectics, based on his intellectual awareness, the philosopher was equipped with the knowledge of the ends and could suggest an eternal good order for any society anywhere and anytime, in Diaeresis, the science of the partial divisions help him only to formulate a timely order peculiar to a definite society. In such a way, the statesman is not anymore a philosopher, but a wise man who is outfitted for the management of the society, not the leader to the truth.

\section{CONCLUSION}

Socratic Elenchus is the method to help man become aware of his ignorance. Due to such knowledge, the one who is unaware of his not-knowing, and thus thinks of himself as knowledgeable, negatively understands the truth (Strauss \& Cropsey 1987, 33). However, there is no way to know the very truth of the subject positively. In other words, in Elenchus, the only clear conclusion is to recognize the border between the doxa and the episteme. As a result, there is no reward other than general comment such as either to live virtually or to follow the laws, or to care about the purity of the soul. 
However, for Plato, who is obsessed with the good order of the polis, it is necessary to propose positive agenda for good leadership. Hence, the post-early Plato finds himself needy of an affirmative method of reflecting on politics. Dialectics, as a philosophical method, was the solution he proposed to solve the problem. Dialectically, now the Platonic philosophy could not only fulfill the negative task of Elenchus but also suggest an uncanny, probative method of thinking on the way to find out what the good society is.

However, to run the positive, eternal model of good governance, the ruler should be capable of knowing the indubitable truth, which is the truth of ideas. Therefore, the philosopher, who is exclusively qualified to achieve such knowledge, is the sole legitimate ruler for whom, according to the awareness of the eternal heavenly model of the good order, no general law or pre-formulation is necessary (Mayhew 2008, 3). Although some scholars (See Pangle, 1980; and Schofield, 2006) suggest that this is the final articulation of Platonic political philosophy, confronting the reality of civic politics led later Plato to reconsider his idealist understanding of good leadership.

Reading the Statesman and the Laws, one might realize that here, unlike the nonsensual genre of the knowledge prescribed in the Republic, the crucial subject of politics is converted into sensual matters. In other words, even though the ruling knowledge is still the theoretical one, in later Platonic dialogues, the first mission of the statesman is to practically direct and rule the society. Indeed, in the era of Zeos, while no total knowledge of the ideas is plausible, the statesman should contemplate the management of the real social order, namely the sensual. So, he needs a kind of knowledge that could enable him to technically understand what the best is now and here in human affairs (Schofield 2006, 140).

Now, what is such knowledge that offers the practical best policy in the polis? Diaeresis, as the knowledge of measurement and dividing, is the answer. Griswold (1998, 174-6) suggests that while in Diaeresis, the politician is led towards the mean metrology of the subjects, he might phronetically make decisions. In other words, the statesman is one who is able to organize the society based on the science of measurement and so to lead the polis to the good order. The problem of leadership is how to make the polis resistant to the challenges, and this leads the leader to the formulation of the laws. Indeed, though later Plato still believes that the laws are always in some ways incomplete and come short of flexibility in different situations, due to its reliance on the long history of human experiences, in the contemporary society attending to the laws is inescapable:

If, I imagine, contrary to laws that have been established on the basis of much experiment, with some advisers or other having given advice on each subject in an attractive way, and having persuaded the majority to pass them- if someone were brazen enough to act contrary to these, he would be committing a mistake many times greater than the other and would overturn all expert activity to a still greater degree than make the written rules (Plato 1997, Statesman: 300b).

In the rest, he concludes that: 
For these reasons, then the second-best method of proceeding, for those who establish law and written rules about anything whatever, is to allow neither individual nor mass ever to do anything contrary to these anything whatsoever (Plato 1997, Statesman: 300b-c).

The political science the statesman should be equipped with is the knowledge to recognize the correct law and to apply it in the polis in such a way that nobody could violate it. Based on the move from the philosophical episteme in Dialectics to the concrete examination of the human experiments in real social life in Diaeresis, the Platonic leader in the Statesman and the Laws should obsess himself with the best way to apply such knowledge in the polis and that is the science of measurement. Hence, in the Laws, the later Plato explains first the general aspects of the political order and the historical developments of the polis (in the third and fourth books), and then the establishment of good political institutions based on the good laws (in the fifth to eighth books), and finally he is capable of introducing the different laws, namely the civic, religious, educative, and punishments, in order to concretely formulate the good order of the real polis he is living in.

In summary, the Platonic journey from the Socratic exploration of the essence of truth to the management of the society has paved the way from Elenchutic understanding of the golden rule of knowledge (and certifying our ignorance of the truth) to the Dialectical positive understanding of the truth exclusive to the philosopher. However, it was not the end. In reality, no concrete society is manageable based on an idealistic eternal articulation of the order. So, it is necessary to equip the ruler with the knowledge of how to decide in real challenges, and human experiences have historically shown that the only authentic matter to rely on in such situations is the formulation of human knowledge, namely the laws. Unlike early Plato, still loyal to Socratic exploration of the truth, the later Plato found it best to rely on the human reality rather than purely intellectual endeavors, which methodologically means Diaeresis.

\section{REFERENCES}

Annas, Julia. 1981. An introduction to Plato's Republic. Oxford, Clarendon Press. Barker, Ernest. 1964. Greek political theory: Plato and his predecessors, New York \& London: Methuen.

Chroust, A. H. 1996. Socrates: A source problem. In Socrates: Critical assessments, Vol. 1. Edited by William J. Prior. London and New York: Routledge, 38-55.

Fine, Gail. 1998. Knowledge and belief in Republic V-VII. In Plato: Critical Assessments, Vol. 2. Edited by Nicholas D. Smith. London and New York: Routledge, 235-265.

Friedlaender, Paul. 1969. Plato 1, An introduction. Translated by Hans Meyerhoff. $2^{\text {nd }}$ Edition, Princeton: Princeton University Press.

Gadamer, Hans-Georg. 1986. The Idea of the good in Platonic-Aristotelian philosophy. Translated by P. Christopher Smith. New Haven: Yale University Press. 
Gomperz, Theodor. 1912. Greek thinkers: A history of ancient philosophy. Vol. 4. Translated by G. G. Berry. Oxford: Balliol College.

Graham, D. W. 1996. Socrates and Plato. In Socrates: Critical Assessments. Vol. 1. Edited by William J. Prior. London and New York: Routledge, 179-201.

Griswold, Charles. 1998. Politike: Episteme in Statesman. In Plato: Critical Assessment. Vol. 4. Edited by Nicholas D. Smith. London and New York: Routledge, 161-186.

Guthrie, W.K.C. 1978. A history of Greek philosophy: The Later Plato and the Academy. Vol. 5. Cambridge: Cambridge University Press.

Jaspers, Karl. 1966. Great philosophers: Plato. Vol. I. London: Harvest Books.

Kahn, Charles. 1995. The place of Statesman in Plato's later work. In Reading the Statesman: Proceeding of the Lii Symposium Platonicum. Edited by C. J. Rowe. Academia Verlag.

Klosko, George. 2006. The development of Plato's political theory. London \& New York: Oxford University Press.

Lane, M.S. 1998. Method and politics in Plato's Statesman. Cambridge: Cambridge University Press.

Lycas, K. 1987. Plato on justice and power: Reading Book I of Plato's Republic. New York: State University of New York Press.

Mayhew, Robert. 2008. Plato Laws: 10, translated with commentary. London \& New York: Oxford University Press.

Morrow, Glenn R. 1993. Plato's Cretan City: A historical interpretation of the Laws. Princeton, New Jersey: Princeton University Press.

Pangle, Thomas. 1980. The laws of Plato. Chicago: University of Chicago Press

Peters, F. E. 1967. Greek philosophical terms: A historical lexicon. New York: New York University Press.

Plato. 1997. Complete Works. Edited with an introduction and notes by John M Cooper. Indianapolis and Cambridge: Hackett Publishing Company.

Plato. 2004. The Republic. Translated by C. D.C Reeve. Indianapolis and Cambridge: Hackett Publishing Company.

Robinson, R. 1996. Elenchus. In Socrates: Critical Assessments. Vol. 3. Edited by William J. Prior. London and New York: Routledge, 9-19.

Ross, David. 1953. Plato's theory of ideas. Oxford: Clarendon Press.

Ross, David. 1996. The Problem of Socrates. In Socrates: Critical Assessments. Vol.

1. Edited by William J. Prior. London and New York: Routledge, 26-37.

Saunders, Trevor J. 1998. Plato's later political thought. In Plato: Critical Assessments. Vol. 4. Edited by Nicholas D. Smith. London and New York: Routledge, 325-347.

Schleiermacher, Friedrich. 1973. Schleiermacher's Introductions to the Dialogues of Plato. Translated by William Dobson. New York: Arno Press.

Schofield, Malcolm. 2006. Plato: Political philosophy. Oxford: Oxford University Press.

Smith, Nicholas. D. 1999. How the prisoners in Plato's cave are like us? In Proceedings of the Boston Area Colloquium13, Leiden, Boston \& Koln: Brill, 187-204. 
Strauss, Leo \& Joseph Cropsey. 1987. History of political philosophy. $3^{\text {rd }}$ edition, Chicago and London: Chicago University Press.

Strauss, Leo. 1975. The argument and action of Plato's Laws. Chicago and London: University of Chicago Press.

Urmson, J. O. 2001. The Greek philosophical vocabulary. London: Duckworth.

Vlastos, Gregory. 1991. The Socratic Elenchus. In Plato I. Edited by Gail Fine. Oxford: Oxford University Press, 36-63. 